\title{
A HOARD FROM THE PERIOD OF THE MONGOL INVASION, DISCOVERED IN THE ABAÚJVÁR FORT
}

Gábor BaKos ${ }^{1}$ - EnIKố Sipos ${ }^{2}$ - Csaba Tóth ${ }^{3}$ - MáRIa Wolf ${ }^{4}$

Hungarian Archaeology Vol. 9 (2020), Issue 4, pp. 53-62. doi: https://doi.org/10.36338/ha.2020.4.3

Research into archaeological traces of the Mongol Invasion has long discovered that hoards consisting of coins, jewellery and other valuables come to light in various parts of the country, and the coins they contain connect these findings to the 1241-1242 attack. In other places, iron objects, predominantly agricultural tools were hidden, and these are usually discovered by accident and not by planned archaeological excavations. This is why the finding that came to light from the Árpád period Abaújvár fort of the count (comes parochialis) in July 2019 is so special. The coins, jewellery, and other unique objects - such as the textile remains woven with golden threads -, as well as the importance of the fort in this period, make it worthwhile to publish the first results briefly, even though the processing of the finds is still ongoing. ${ }^{5}$

\section{THE SITE}

The fort of Abaújvár was built on a small, solitary hill right next to the Hernád river, in the foreground of the Zemplén Hills, at the present-day border between Slovakia and Hungary (Fig. 1). The almost perfectly preserved ramparts surround an area of ca. 3.9 hectares, the highest point rising $15 \mathrm{~m}$ above the Hernád river and $5 \mathrm{~m}$ above the fort's inner yard. The only entrance to the fort opened to the east, where a ditch served as an extra line of protection (this has already been filled up) (Fig. 2).

The fort served as the centre of the historical county of Abaúj, one of the counties founded by King Stephen I; the fort was already standing in the first third of the 11th century (GYÖRFFY 1977, 209; KRISTÓ 1988, 400). The north-south oriented military and trade route that led to Russia and Poland, called 'Abanagyúta' (Aba's Great Road), 'Nagy út' (Great Road), or 'Királyúta' (the King's Road) in the medieval sources, played a crucial role in the foundation and development of the fort (GYÖRFFY, 1963, 53). At the same time, Abaúj was a county on the border in the Árpád period, and so its primal function was to protect the northern frontier. It is mentioned first in this context: a 1068 document reveals a soldier's name who served here (GYÖRFFY 1963, 45; KRISTÓ 1988, 400). The fort was also mentioned several times in the chronicles in connection with the 11th-century struggles for the crown and the pagan uprisings; for example, it was in the Abaúj fort that Prince Andrew, returning from Russia in 1046, was recognized by the Hungarian lords as king. Andrew stayed here with his army in September 1046 (SRH I. 337). The fort was an important centre of the Hungarian Kingdom in the 11th-13th centuries and sparked researchers' interest already in the 19th century. After the ground-breaking research that started in that period, Judit Gádor conducted proper excavations in the fort in 1974-1981. During this survey, important information was collected about the ramparts as well as the church inside the fort and the cemetery around it.

The earth-and-wood rampart structures that served as walls had been built on top of the remains of a 3rd-4th-century settlement in the 11th century. The rampart had a wooden frame, built mainly of wood in the rough. The timbers were piled up perpendicular to each other, as if building a bonfire, and the gaps in this

\footnotetext{
Herman Ottó Museum, Miskolc. E-mail: b.gabor@hotmail.com

Hungarian National Museum, Budapest. E-mail: siposeni@gmail.com

Hungarian National Museum, Budapest. E-mail: toth.csaba@hnm.hu

4 Institute of Archaeology, University of Szeged. E-mail: wolfmaria55@gmail.com

5 This study was made possible by the support of the National Research, Development and Innovation Office, through the project "The Mongol Invasion of Hungary and Its Eurasian Context" (K 128 880). We hereby thank the Metal Detectorist Volunteers of the Herman Ottó Museum, Ferenc Bánfaly, Judit Kozmáné Bányi, and Andrásné Sáfrány, as well as the colleagues at the Herman Ottó Museum and the enthusiastic locals for their indispensable help and support during the discovery and processing of the finds.
} 
Gábor Bakos et al $\bullet$ A Hoard from the Period of the Mongol Invasion, Discovered in the Abaújvár Fort

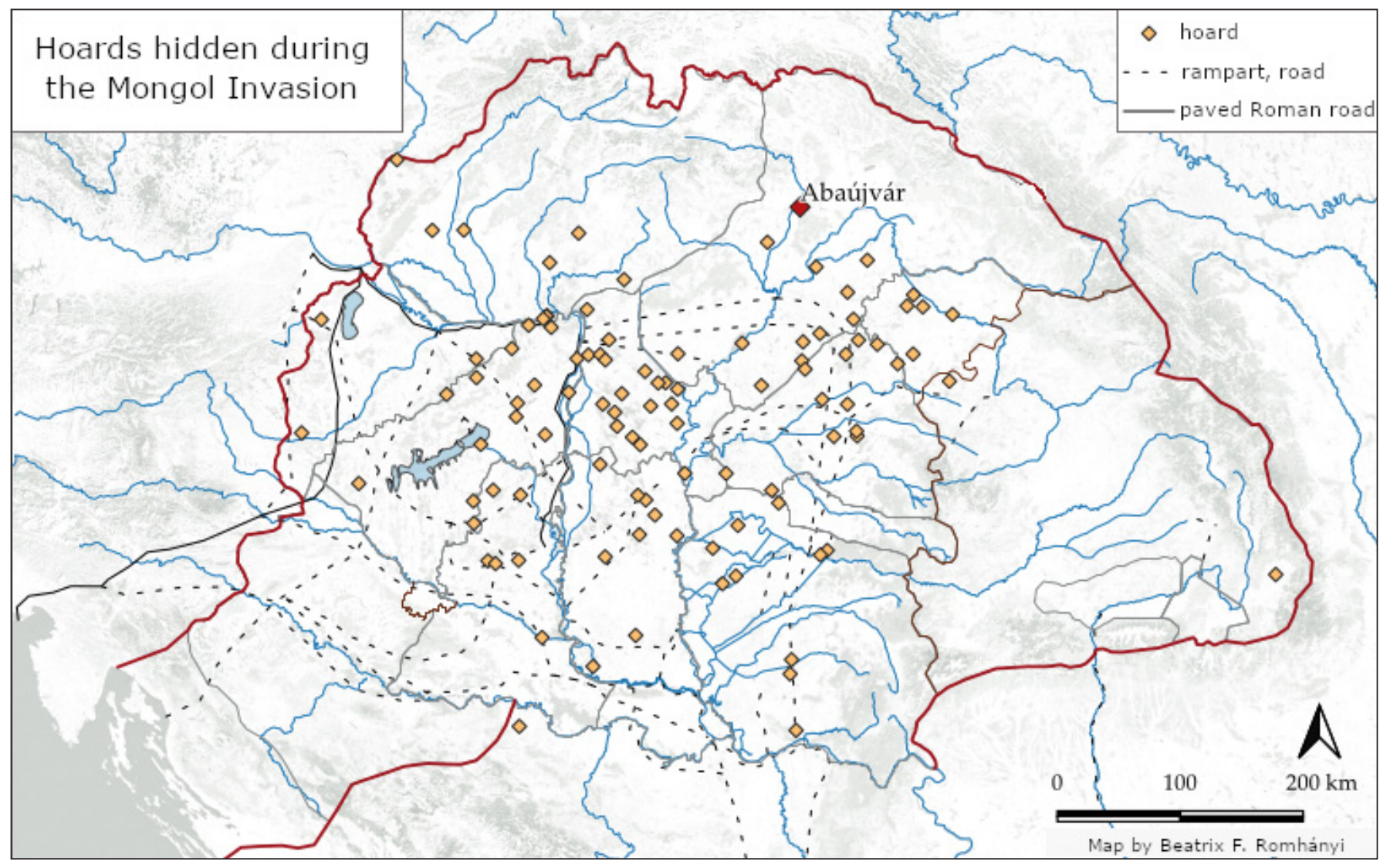

Fig. 1. The Abaújvár fort and the location of hoards from the period of the Mongol Invasion, shown on the map of medieval Hungary

irregular structure were filled in and packed with soil. The rampart was originally 23 metres wide, and it must have been ca. 9 metres high, although only 5 metres remain today. Remains of a stone wall segment were also found during the excavation; this was built on top of the rampart and was 4 metres wide and 0.5 metre high (GÁdOr \& NovÁKi 1976a, 37-47; GÁdOR \& NovÁKi 1976b, 425-434; GÁdOR \& NovÁKi 1980, 43-76).

A large church dated to the second half of the 11th century was also found within the fort; in all probability, this must have been the seat of the dean who governed the ecclesiastical institutions in the county. This hypothesis may be supported by an ornamented tombstone discovered in the cemetery around the church, which is dated to the turn of the 11th-12th centuries and must have belonged to a clergyman, possibly the first dean. A cemetery of several hundred burials came to light around the church, and the finds suggest that it was used between the 11th and 14th centuries (GÁDOR 1980, 443-450). The earliest finds of the site originate from the 11th century, dated by a silver coin minted during the reign of Andrew I (1046-1061).

Among the most valuable findings is a circle-shaped seal (matrix) made from a bronze sheet. On its front side the figure of a man is engraved, holding a narrow shield in his left and a hatchet with a long handle in his right hand. The figure is placed in the middle, and the inscription around it reads Sigillu Lazari Iudices, that is, the seal of judge Lazarus. The seal can be dated to the second half of the 12th century (GÁDOR, 1988, 129-136; Wolf, 1999, 288, Kat. 48).

A hidden hoard was also discovered during this earlier excavation; it consisted of agricultural tools, two sickles, two spade mounts, and a knife used to prune vine; these objects were dated to the 12th-13th centuries (GÁDOR \& NovÁKI 1976a, 40-45; GÁDOR

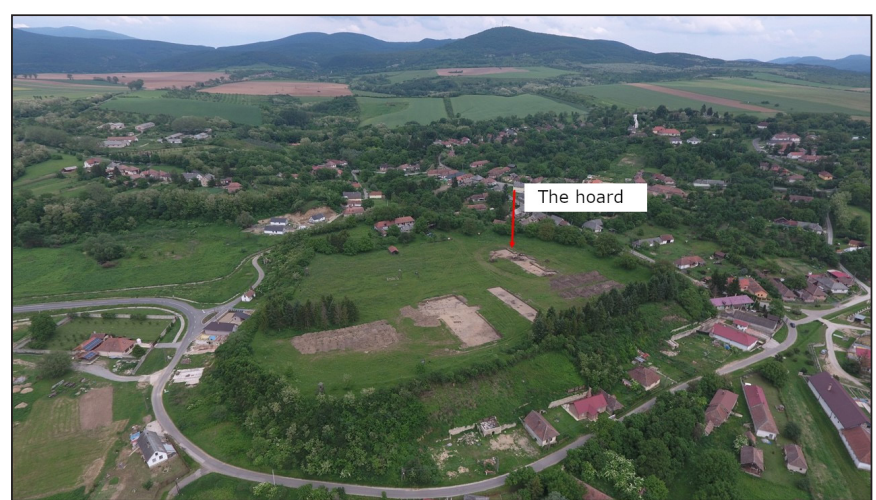

Fig. 2. The Abaújvár fort (photo by Árpád Balogh) 
\& NovÁKi 1976b, 431-434; MÜller 1982, 25-26). However, this archaeological survey stopped in 1981, and the internal part of the fort was not excavated. In present-day Hungary, there are only a few early centres the internal parts of which can be investigated by archaeological methods, and so it was pivotal to continue examining the Abaújvár fort. Continuing this research had the potential to shed light on the role of 11 th-13th-century centres as well as the everyday life in them.

In 2019, the so-called House of Árpád Program provided an opportunity to conduct new archaeological surveys. This time we unearthed 153 archaeological features dated to various periods, in an area of $2270 \mathrm{~m}^{2}$. Most of the features originate from the Árpád period. The most important finding is a large palace building with stone foundations and a colonnade. During the excavation of the eastern foundation wall of the palace, two coins came to light, an anonymous denarius from the 12th century, and a copper coin minted during the reign of Bela III. This suggests that the palace was built in the 12th century.

\section{THE TREASURE}

Metal objects were found in large numbers during our excavation. This is partly due to the help of metal detectorist volunteers of the Herman Ottó Museum who actively contributed to the work from the beginning. This is one of the reasons why we consider the cooperation between enthusiasts and archaeologists to be of crucial importance. The continuous use of metal detectors is an important contribution also from a methodological point of view, because at such a densely and intensively used multi-period site there is a high number of tiny artefacts dated to different periods that are hard to collect, being buried in varying depths.

First, we noted several coins that exhibited a characteristic green spot where they stuck together; they concentrated in an area of $5 \times 8$ metres. In addition to the coins, a number of modern metal objects and iron artefacts were detected. As coins continued to appear, we came to the conclusion that this was a coin hoard that was ploughed or disturbed in other ways, and we hoped to find its core somewhere under the agriculturally disturbed layers. After removing the modern objects from the area, it became possible to locate the hoard and excavate it properly. In the first phase of uncovering the remains, it became clear that the pot containing the hoard was buried in a shallow pit and a plough destroyed parts of its mouth, thus bringing to the surface the coins that we first found. A proper trench was opened in order to see the spatial relations, and so the exact location of the pot as well as the tool with which the pot was buried were found. Although the pot was broken, its pieces were collected and so it could be restored. Some elements of the hoard were scattered nearby, but with the help of metal detectors we were able to collect the whole cache.

The find consists of altogether 890 coins, four silver and a bronze buckle, two silver and two golden rings, two pairs of silver earrings and three additional, drop-shaped earring parts, one silver ring that probably belonged to an earring, four golden knobs with gems, one piece of rock crystal that must have belonged to a ring or a pendant, a heavily worn Roman silver coin, a small metal artefact in the shape of a fleur-de-lis, and pieces of textiles interwoven with a golden thread (Fig. 3). The composition of the hoard corresponds to caches dated to the Mongol Invasion; these usually include Hungarian and foreign coins as well (Tóth 2007; V. SzÉKely 2014). ${ }^{6}$ In this case, this ratio was 70:30, with the dominance of Hungarian coins. The earliest Hungarian coins were two denarii (H276) issued by Andrew II (1205-1235); in addition to these, there were five different types of bracteates of Bela IV (12351270 ) in the hoard (H191/4 pieces, H192/140 pcs, H195/114 pcs, H199/24 pcs, H200/24 pcs), 302

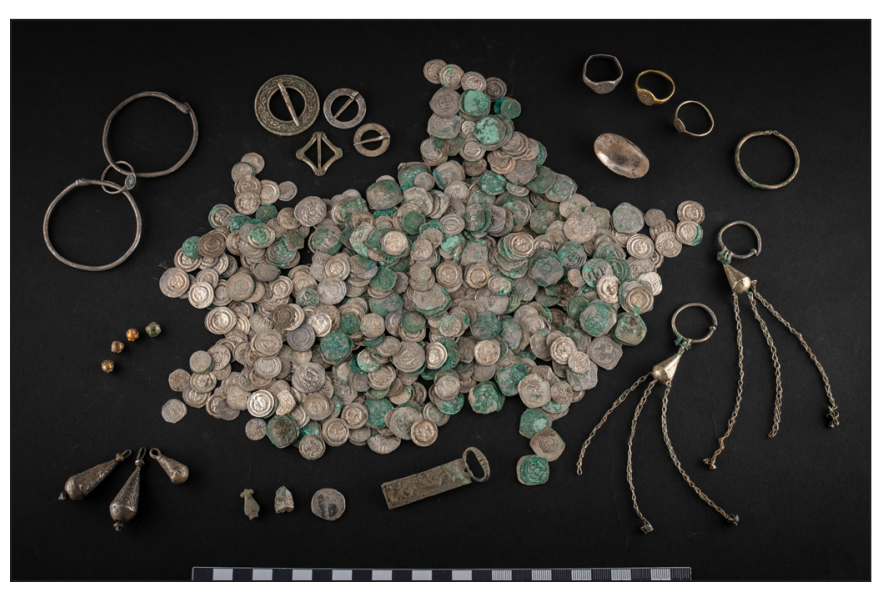

Fig. 3. The hoard before restoration (photo by Benedek Baranczó)

6 We hereby thank Szilárd Tóth for the identification of the foreign coins. 
pieces of silver denarii also minted during the reign of the latter king (H69), as well as eight silver coins that have not yet been identified. The foreign coins also reflect the usual compound of hoards in the period. Nearly all of these were so-called Friesach denarii; most of them were well identifiable official coins, although counterfeit pieces were also present. Friesach denarii were originally high-quality silver coins minted by the archbishop of Salzburg in Friesach, Carinthia from the first half of the 12th century onwards. Later this name was applied to coins minted by other ecclesiastical and lay authorities, such as the princes of Carinthia and Styria, the counts of Andesch-Meran, the bishops of Gurk and Bamberg, and the patriarchs of Aquileia, in the

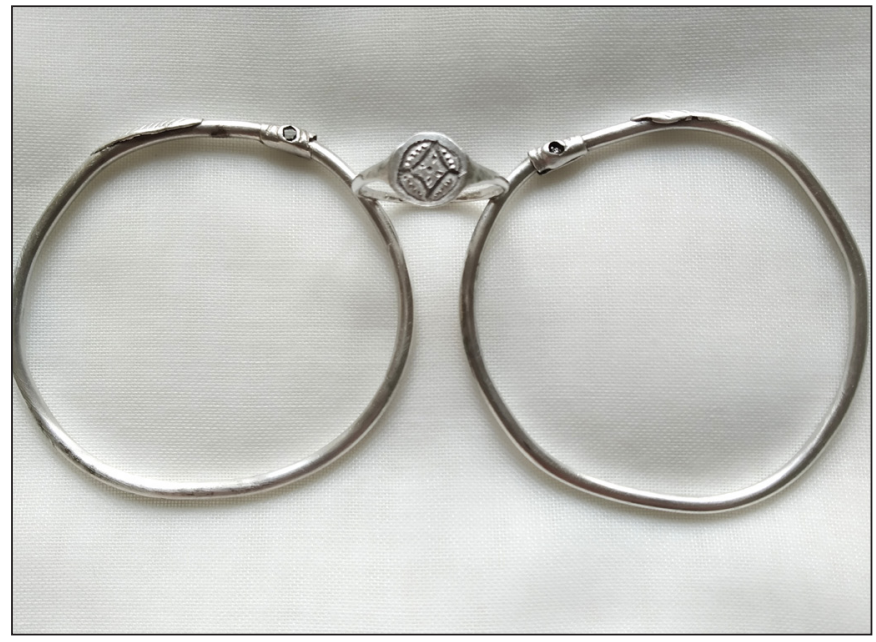

Fig. 4. Socketed rings and a women's ring with niello decoration (photo by Judit Kozmáné Bányi) 12 th-13th centuries; especially the denarii issued in Carinthia and Carniola were called by this name. In this hoard, the earliest of such denarii are dated to the last third of the 12th century, the so-called Eriacensis period, and were probably issued by Adalbert, bishop of Salzburg between 1170 and 1200. Coins issued by contemporaries of Andrew II and Bela IV, that is, bishop of Salzburg Eberhard II (1200-1246), Bernhard, prince of Carinthia (1202-1256), and Berthold, patriarch of Aquileia (1218-1251) were found in the largest numbers. In addition to these, products of minor mints are also present in small numbers, usually one coin from each, and one coin from Graz was also identified. It is interesting that Vienna denarii are missing from the hoard, but the assemblage contained four denarii minted in Cologne, and one English short-cross penny from the early 13 th century.

The composition of the hoard corresponds to findings dated to the Mongol Invasion. The hoard is most reliably dated by the foreign coins, the latest of which were made in the 1230 s according to present Austrian scholarship. The composition of the hoard, as well as the method it was hidden, the artefacts included in it and the material they were made of are by no means exceptional in the context of mid-13th century caches connected to the Mongol Invasion. Jewellery and money were usually buried in pots. The jewellery was typically made of silver or electrum; golden objects were found in a few cases as well (PARÁDI 1975, 148). Artefacts hidden this way often include socketed rings (JAKAB 2007, 249, 255-256; PARÁDI 1975, 124). A pair of this type of jewellery, made of a silver wire, was found in Abaújvár as well (Fig. 4). Rock crystals that belong to pendants or rings and had been taken out of their mounting, are also customary parts of such hoards (PARÁDI 1975, 126, 138). Different types of rings also frequently come to light from such assemblages; most often, these are decorated with fleur-de-lis, geometric, or Agnus Dei motifs; earlier research

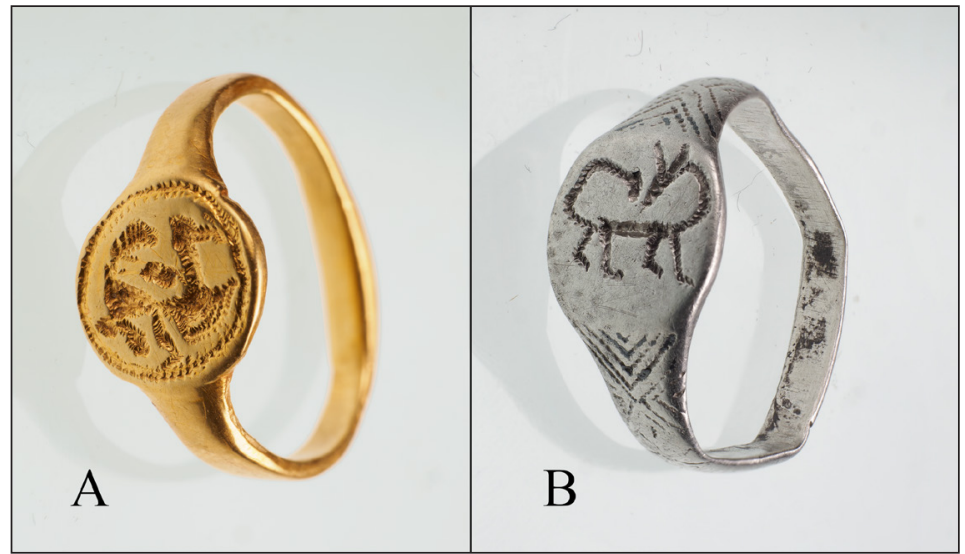

Fig. 5. Men's rings decorated with mythical creatures (photo by Csaba Gedai) identified them as seal rings. The ones found at Abaújvár, however, have different ornamentation. A women's ring made of gold had a niello cross on its head. The other women's ring is made of silver and is ornamented with a geometric motif, which is not engraved but was applied on the niello in a different colour. One of the two men's rings is made of gold, the other of silver. Both their heads are decorated with engraved animal figures; on the silver ring, there is an animal looking backwards, with its tail raised. Rings with similar decorations have been brought to light from cemeteries as well as from hoards dated to the 
Gábor Bakos et al $\bullet$ A Hoard from the Period of the Mongol Invasion, Discovered in the Abaújvár Fort

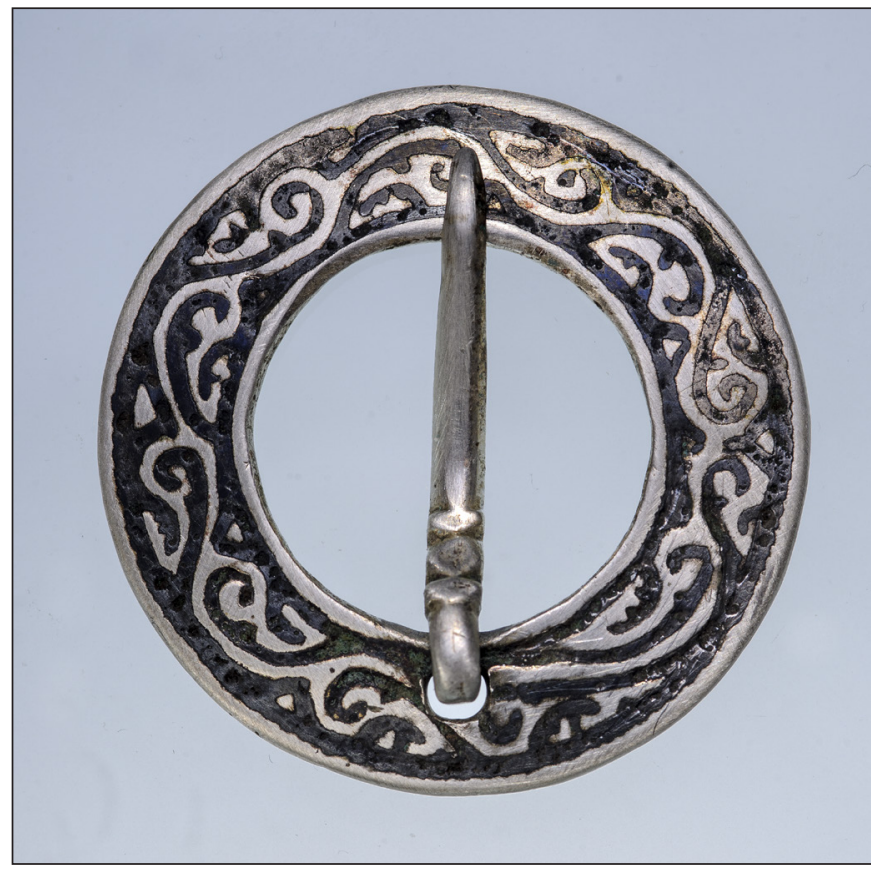

Fig. 6. Buckle with niello decoration (photo by Csaba Gedai)

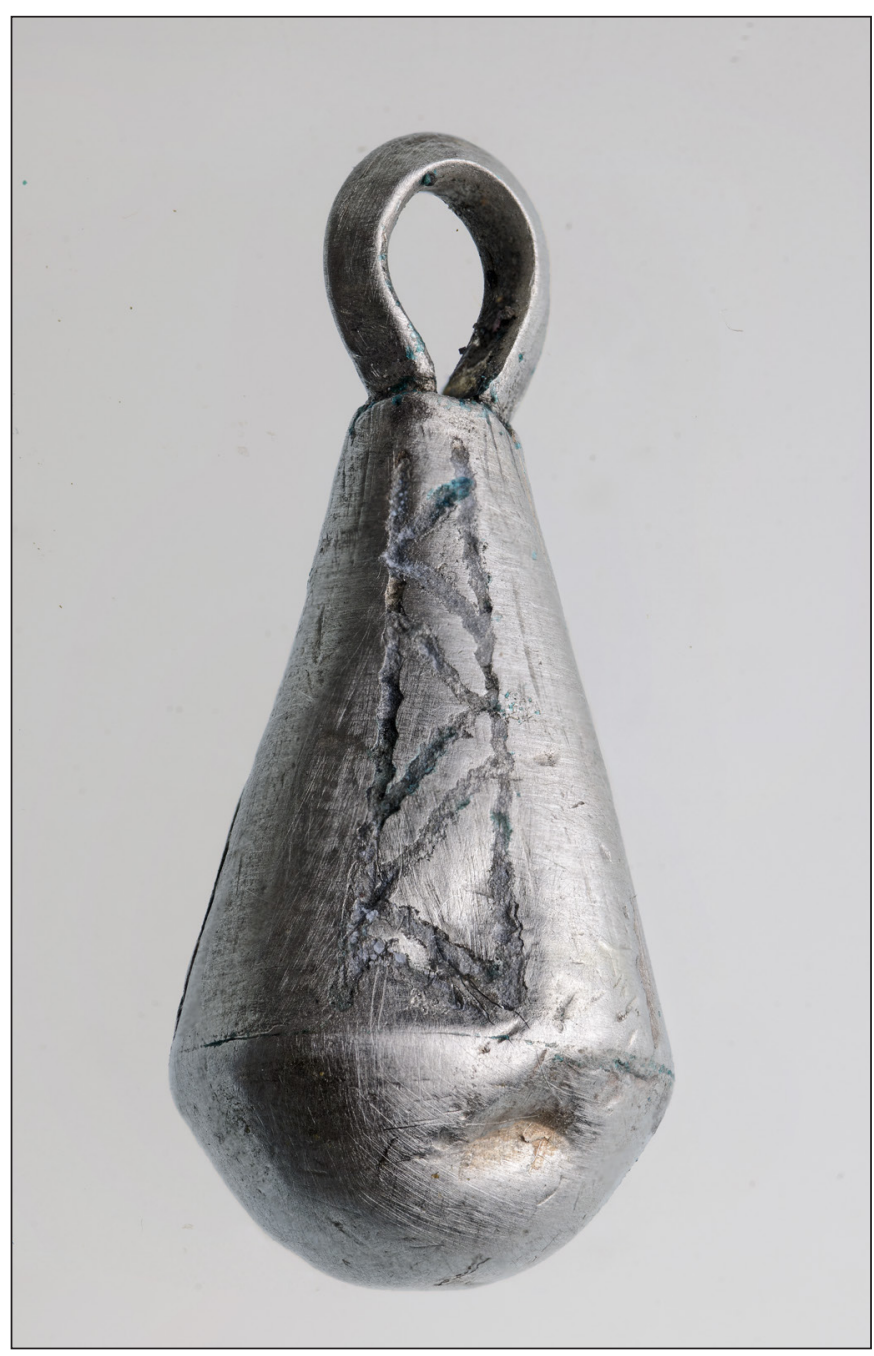

Fig. 8. The drop-shaped pendant of one of the earrings, decorated with niello (photo by Csaba Gedai)

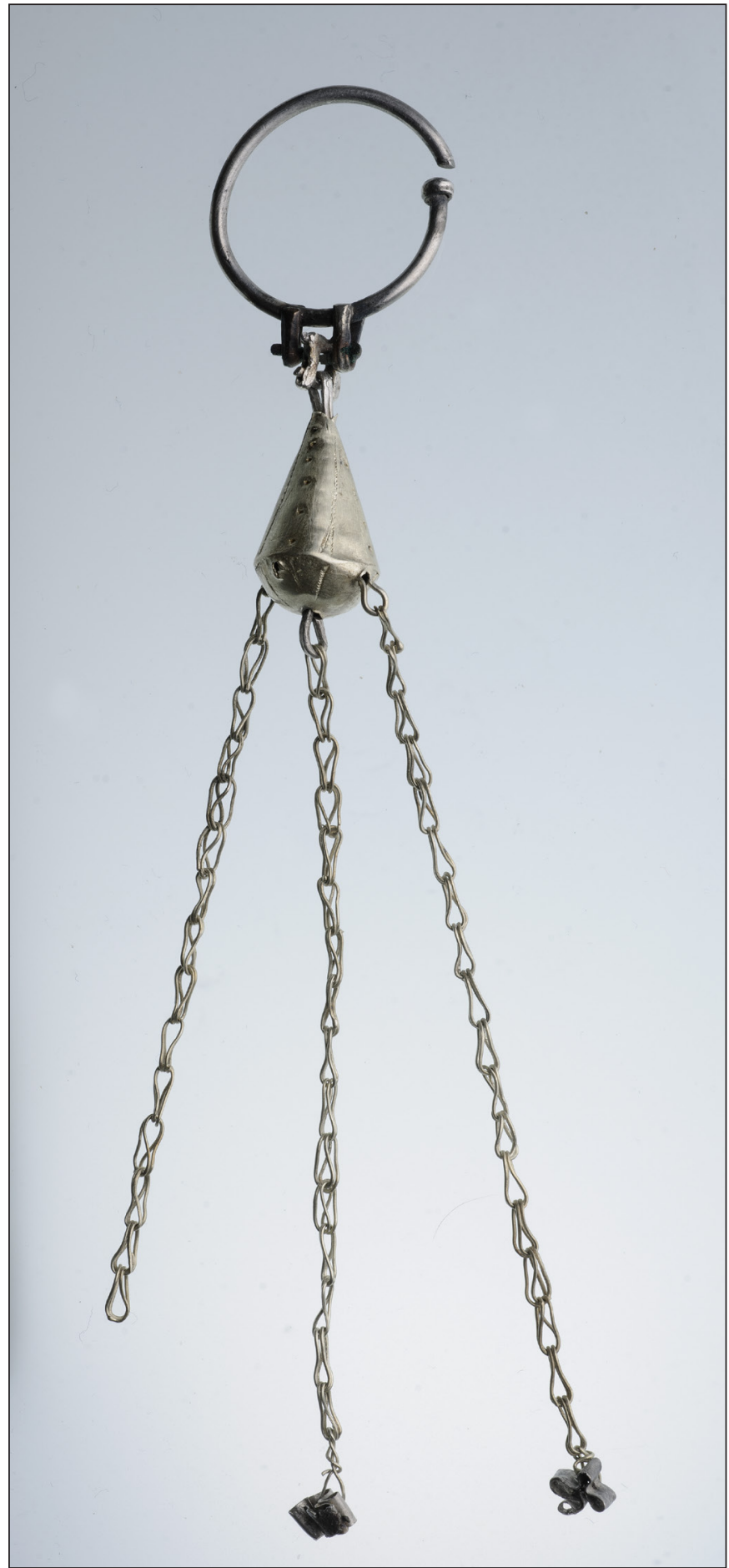

Fig. 7. A well-preserved earring with a small chain and a pendant (photo by Csaba Gedai)

Mongol Invasion, although only in small numbers. The animal figure on the golden men's ring, however, differs from these, and resembles mythical creatures, such as dragons, griffons, or senmurvs, with which earlier research identified such animal figures (RózSA \& SzIGETI, 2019, 80; Fig. 5). Hoards often include various types of buckles and clasps. The buckle found in the Abaújvár hoard, decorated 
with niello, is unique in its kind (Fig. 6). The earrings with small chains and a pendant are also rarities (Fig. 7). One pair is almost completely intact, while only the drop-shaped pendants were preserved of the other pair (Fig. 8). Two of these were decorated with niello. Analogies are known only from two archaeological sites: three earrings with chains and pendants, one of them made of gold, were discovered in a contemporary hoard at Tyukod-Bagolyvár (JAKAB 2007, 253, Figs. 11-13), and a silver piece came to light from a hoard in Kelebia (HАтнÁzi 2005, 107-110, Figs. 96-98). Further analogies are known from the Balkans and Byzantium, from present-day Serbia, Bulgaria, Ukraine and Russia (HATHÁzi 2005, 110; JAKAB 2007, 258-259). So, these pieces must have been brought here by trade. In all probability, the rest of the objects with niello decoration also found their way to medieval Hungary via trade; niello decoration was not customary in 11th-13th-century Hungarian metalsmithing (KISS 2007, 62, 64, footnote 36; PÁLÓCZI HoRVÁTH 2014, 31-32).

The most intriguing find, however, is without doubt the textile pieces. They were very poorly preserved, fragmented, dried out and creased up. It was striking, however, that the surface of the golden threads remained clean and shiny, with no traces of corrosion; that is why we spotted it. During restoration it became clear that these are the remains of three types of textile. One of them is a piece of linen, which was preserved adhered to the coins; in all probability, this was a cloth into which the money was wrapped when it was placed in the pot. The second textile was made of plain-woven silk, with crossing silk stripes that imitated seersucker, repeating in every $4 \mathrm{~mm}$. The textile was hemmed lengthwise on both side with a $4 \mathrm{~mm}$ wide hem (Fig. 9). The metal thread was exceptionally fine; its examination ${ }^{7}$ revealed that it was cut out from a thin, gilded sheet with scissors, in a spiral shape,

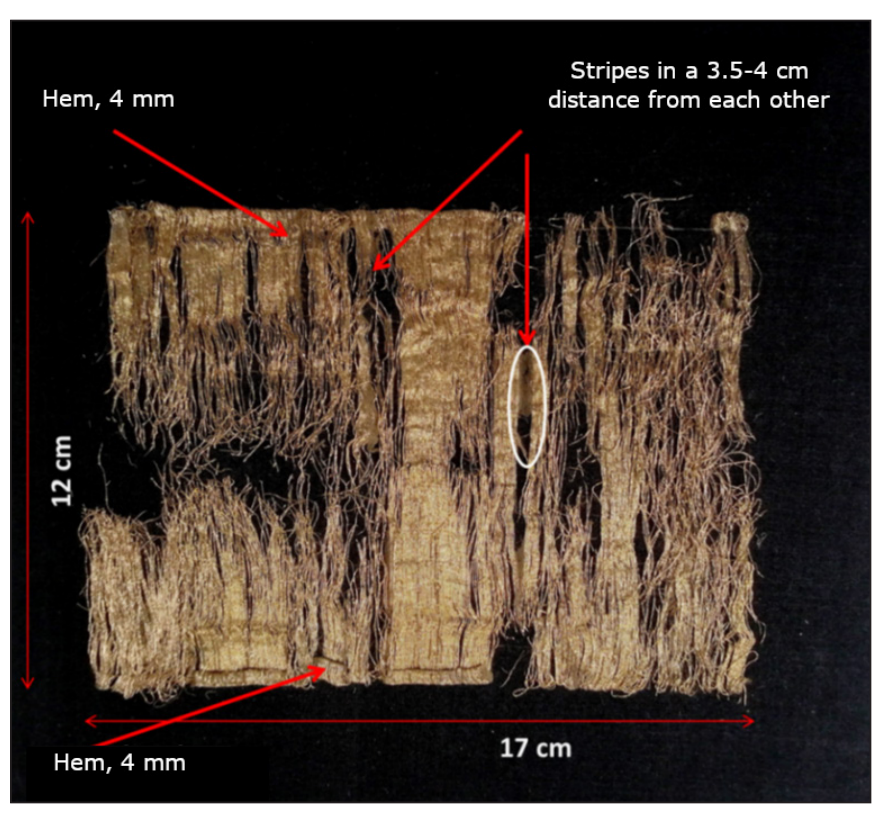

Fig. 9. Fragment of the bonnet (photo by Enikö Sipos) and then it was entwined around a silk thread. The third textile remnant had a more densely woven fabric and was thicker than the other two. The metal thread was woven into it to form a zigzag pattern, while on one side there were also decorative stripes of metal thread (Fig. 10).

The width of the textile decorated with golden threads, the hem on both of its sides and the structure of the fabric, as well as the seersucker motif indicate that these pieces must have belonged to a bonnet. Bonnets were decorative headgears typical for the 13th century. They consisted of two main parts: a linen headband and a chin strap. The width of the latter varied between 10 and $15 \mathrm{~cm}$, but it could be as long as 6 metres. On the top of this headgear, caps and crowns were worn, while sometimes a net covered the hair underneath the bonnet. A veil could also be added to the gear; this was sometimes worn under, sometimes above the bonnet (DAVENPORT 1948, 151).

Very few textile remains of this kind are known from Hungary. Large pieces of a similar cloth were brought to light from the grave of Anna of Antioch, wife of King Bela III; these were probably parts of a headgear, a lace headdress made with golden threads and a veil also hemmed with golden thread (Kovícs 1998, 116, note 3; SiPos 1999, 60-68). Recent excavations at Szank unearthed remains of a small, plain-woven fabric (Sz. Wilhelm 2014, 85). In Perkáta, one of the Árpád period features in the cemetery around the church yielded a piece of cloth with an interwoven golden thread (HAtHÁzi \& Kovícs 2014, 255, Fig. 22). Without doubt, such pieces were very expensive in the mid-13th century; the value of this piece is also sug-

The examination was conducted by Levente Illés (Institute of Technical Physics and Materials Science, Hungarian Academy of Sciences), to whom we are grateful for his work. 
Gábor Bakos et al $\cdot$ A Hoard from the Period of the Mongol Invasion, Discovered in the Abaújvár Fort

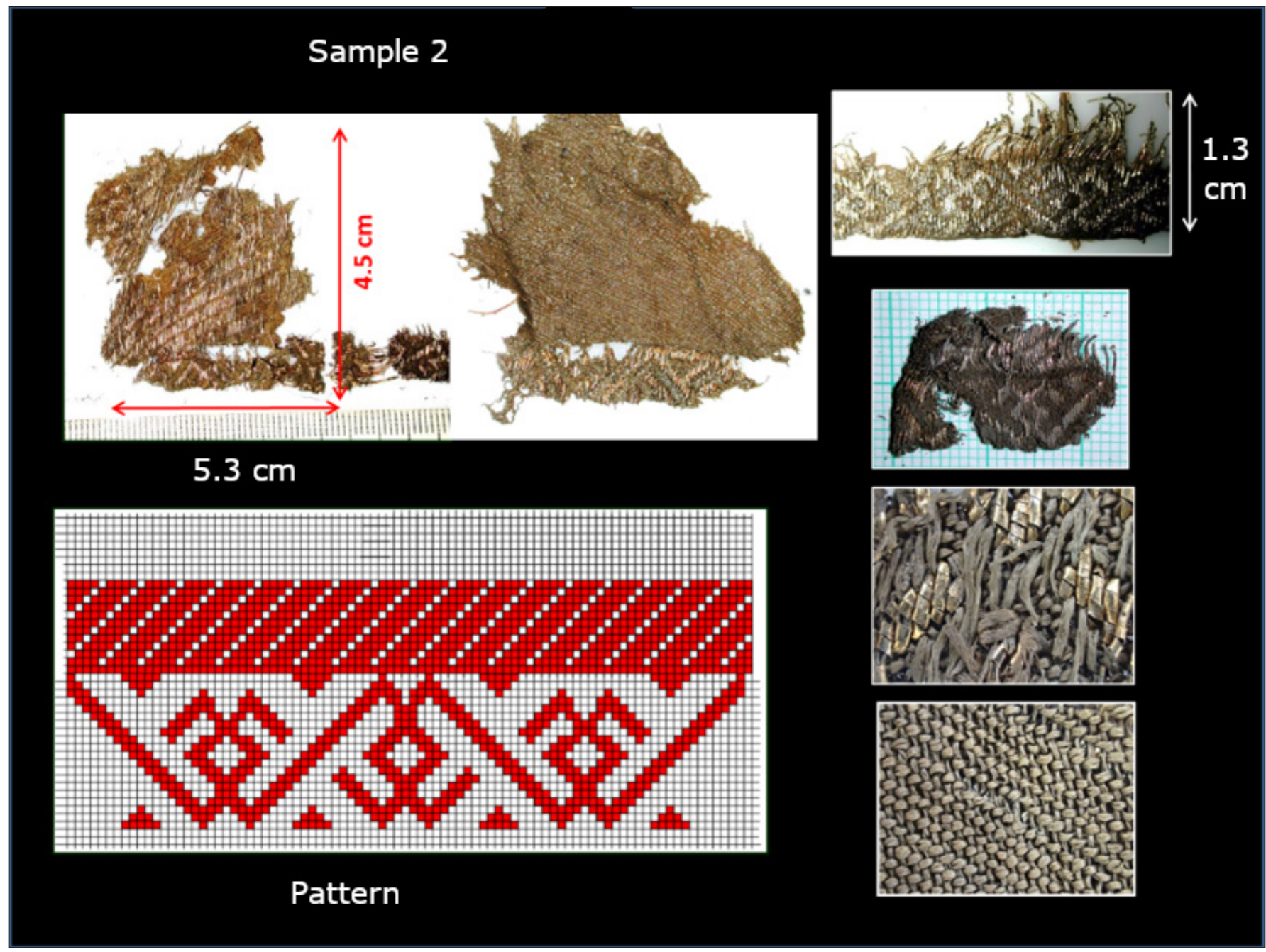

Fig. 10. Another fragment of the bonnet (photo by Enikö Sipos)

gested by the fact that the bonnet was hidden next to the money and the jewellery. As for its origin, it must have been brought to Hungary by trade, and was probably made in Byzantium, the great textile making centre in this period.

\section{CLOSING REMARKS}

Not far from the hoard, next to the fort's rampart, another trove was found, which consisted of an iron ploughshare and three iron coulters. These, together with the other agricultural tools unearthed here during earlier excavations, suggest that Abaújvár's role in the Mongol Invasion should be revisited. The fort is mentioned in a letter written by the Hungarian lords to the pope, signed on 2 February 1242, in which they listed those Hungarian forts that could have served as starting points of a counterattack against the Mongols (Katona 1981, 311-313). On this side of the Danube, only seven forts are named, with Abaújvár among them. The letter suggests that Abaújvár was the strongest fort in North-East Hungary in that time. However, no evidence has surfaced so far that would suggest that the fort was indeed attacked by the Mongols, although it was on the way of the Mongol army led by Batu Khan as they were coming from the Verecke Pass. The hidden jewellery, money, and iron objects - the latter were considered just as valuable - suggest that the fort was in peril, and some of its inhabitants fled or died and could not come back for their valuables. Two graves, found in a relatively large distance from the church and the cemetery around it, also seem to evidence the attack against the fort. In one of the graves, a young person was buried whose legs were missing from the knee down; his coffin was richly ornamented with mounts. One spur was found in the 
coffin beside his body. The other grave came to light right next to the hoard; here, a man and a child were buried, also in a coffin decorated with mounts. Both the spur and the mounts are dated to the second half of the 13th century, and therefore it is strange that these people, laid in ornamented coffins, were interred far from the proper cemetery. It may not be a far-fetched hypothesis that they died during the Mongol attack.

The finds that came to light both in the excavation area and outside of it suggest that this fort of the count was attacked by the Mongol army. The written sources as well as the archaeological remains show that the fort survived the siege and it may have served as an important hub in the actions of counterattack. Further surveys inside the fort and in the rampart can contribute to a better understanding of the role this fort played in the history of the Mongol Invasion.

\section{RECOMMENDED READINGS}

Laszlovszky, J., Pow, S. \& Pusztai, T. (2016). Reconstructing the Battle of Muhi and the Mongol Invasion of Hungary in 1241: New Archaeological and Historical Approaches. Hungarian Archaeology 5/7 [2016 Winter], 29-38.

Vargha, M. (2015). Hoards, Grave Goods, Jewellery. Objects in Hoards and in Burial Contexts during the Mongol Invasion of Central-Eastern Europe. Oxford - Budapest: Archaeopress.

\section{BIBLIOGRAPHY}

Davenport, M. (1948). The Book of Costume, Feudal Lords and Kings XIII c. New York: Crown.

Gádor, J. (1980). Ausgrabung in der Erdburg von Abaújvár. Eine Kirche in der Gespanschaftsburg. Acta Archaeologica Academiae Scientiarum Hungaricae 32, 443-454.

Gádor, J. \& Nováki, Gy. (1976a). Ásatás az abaújvári földvárban [Excavations in the Abaújvár fort]. Herman Ottó Múzeum Évkönyve 15, 37-47.

Gádor, J. \& Nováki, Gy. (1976b). Ausgrabung in der Erdburg von Abaújvár. Acta Archaeologica Academiae Scientiarum Hungaricae 28, 425-434.

Gádor, J. \& Nováki, Gy. (1980). Az abaújvári földvár sánca [The rampart of the Abaújvár fort]. Herman Ottó Múzeum Évkönyve 19, 43-77.

Györffy, Gy. (1963). Az Árpád-kori Magyarország történeti földrajza [The historical geography of Árpád period Hungary]. Vol. I. Budapest: Akadémiai Kiadó.

Györffy, Gy. (1977). István király és müve [King Stephen and his work]. Budapest: Gondolat.

Huszár, L. (1979). Münzkatalog Ungarn von 1000 bis heute. Budapest - München: Corvina - Battenberg.

Hatházi, G. (2005). Sirok, kincsek, rejtélyek: Híres középkori régészeti leletek Kiskunhalas környékén [Graves, treasures, mysteries: Famous archaeological findings around Kiskunhalas]. Kiskunhalas: Thorma János Múzeum. 
Gábor Bakos et al $\bullet$ A Hoard from the Period of the Mongol Invasion, Discovered in the Abaújvár Fort

Hatházi, G. \& Kovács, L. O. (2014). Árpád-kori falu és kun szállás Perkáta-Nyúli-dűlő lelőhelyen [Árpád period village and Cuman camp at the site of Perkáta-Nyúli dülő]. In Sz. Rosta \& Gy. V. Székely (eds.), Carmen miserabile. A Tatárjárás magyarországi emlékei. Tanulmányok Pálóczi Horváth András 70. születésnapja tiszteletére (pp. 241-270). Kecskemét: Katona József Múzeum.

Jakab, A. (2007). Tatárjárás kori kincslelet Tyúkod—Bagolyvárról [A treasure find from Tyúkod-Bagolyvár, dated to the Mongol Invasion]. A Nyíregyházi Jósa András Múzeum Évkönyve 49, 244-296.

Katona, T. (ed.) (1981). A tatárjárás emlékezete [The memory of the Mongol Invasion]. Budapest: Európa.

Kovács, É. (1998). Species Modus Ordo. III. Béla és Antiochiai Anna halotti jelvényei [The death insignia of Béla III and Anna of Antioch]. Budapest: Szent István Társulat.

Kiss, E. (2007). Ötvösség és fémmüvesség Magyarországon a Tatárjárás idején [Metalsmithery and metalworking in Hungary in the time of the Mongol Invasion]. In Á. Ritoók \& É. Garam (eds.), A Tatárjárás 1241-42 (pp. 60-68). Budapest: Magyar Nemzeti Múzeum.

Kristó, Gy. (1988). A vármegyék kialakulása Magyarországon [The development of counties in Hungary]. Budapest: Magvető.

Müller, R. (1982). A mezögazdasági vaseszközök fejlödése Magyarországon a késővaskortól a törökkor végéig [The development of agricultural tools in Hungary from the late Iron Age to the end of the Ottoman Turkish period]. Zalai Gyüjtemény 19. Zalaegerszeg: Zalai Megyei Levéltár.

Parádi, N. (1975). Pénzekkel keltezett XIII. századi ékszerek. A nyáregyháza-pusztapótharaszti kincslelet [13th-century jewellery dated with the help of coins. The treasure find from Nyáregyháza-Pusztapótharaszti]. Folia Archeologica 26, 119-161.

Pálóczi Horváth, A. (2014). Keleti népek a középkori Magyarországon [Eastern peoples in medieval Hungary]. Budapest - Piliscsaba: Archaeolingua - Pázmány Péter Katolikus Egyetem.

Rózsa, Z. \& Szigeti, J. (2019). A kincset őrző oroszlánok: egy különleges gyürütípus a tatárjárás előestéjén [Lions guarding the treasure: a special ring type in the eve of the Mongol Invasion]. Határtalan Régészet $4 / 2,78-82$.

Sipos, E. (1999). Textiltöredékek Antiochiai Anna sírjából [Textile fragments from the grave of Anna of Antioch]. In V. Cserményi (ed.), 150 éve történt... III. Béla és Antiochiai Anna sírjának fellelése (pp. 6068). Szent István Király Múzeum közleményei, B sorozat 49. Székesfehérvár: Szent István Király Múzeum.

SRH: Sriptores rerum Hungaricarum tempore ducumregumque stirpis Arpadianae gestarum. Edendo operi praefuit Emericus Szentpétery. I-II. Budapestini 1937-1938.

V. Székely, Gy. (2014). Tatárjárás és numizmatika - Egy történelmi katasztrófa pénzforgalmi aspektusai [The Mongol Invasion and numismatics - Monetary aspects of a historical catastrophe]. In Sz. Rosta \& Gy. V. Székely (eds.), Carmen miserabile. A Tatárjárás magyarországi emlékei. Tanulmányok Pálóczi Horváth András 70. születésnapja tiszteletére (pp. 331-344). Kecskemét: Katona József Múzeum.

Sz. Wilhelm, G. (2014). „Akiket nem akartak karddal elpusztítani, tüzben elégették” - Az 1241. évi tatárpusztítás nyomai Szank határában ["Those whom they did not want to kill by the sword, they burnt in 
Gábor Bakos et al $\cdot$ A Hoard from the Period of the Mongol Invasion, Discovered in the Abaújvár Fort

fire" - Traces of the 1241 Mongol destruction in the outskirts of present-day Szank]. In Sz. Rosta \& Gy. V. Székely (eds.), Carmen miserabile. A Tatárjárás magyarországi emlékei. Tanulmányok Pálóczi Horváth András 70. születésnapja tiszteletére (pp. 81-109). Kecskemét: Katona József Múzeum.

Tóth, Cs. (2007). A tatárjárás korának pénzekkel keltezett kincsleletei [Hoards from the period of the Mongol Invasion, dated by coins]. In Á. Ritoók \& É. Garam (eds.), A Tatárjárás 1241-42 (pp. 79-90). Budapest: Magyar Nemzeti Múzeum. 